\title{
IMPACT OF LAND USE ON CLIMATE CHANGE
}

\author{
Katarzyna Kocur-Bera \\ University of Warmia and Mazury in Olsztyn, Poland \\ katarzyna.kocur@uwm.edu.pl
}

\begin{abstract}
The aim of the study was to develop a method for shaping the safe space of rural areas in view of the increasingly frequent extreme weather phenomena resulting from climate change. The study was carried out on the assumption that geographic data, which decrease or increase the risk of financial loss caused by extreme weather events, can be identified. A group of selected characteristics was used to construct a synthetic parameter for measuring an entity's vulnerability to financial loss, based on the existing conditions in the evaluated area. The developed parameter was referred to as the vulnerability index, which value determines a community's sensitivity to extreme weather phenomena. The vulnerability index was used in further analyses. In the next step of the study, changes in the values of the proposed index were evaluated in scenarios, where adaptive measures were and were not implemented. Three types of scenarios were analyzed: baseline, optimistic and pessimistic. The adopted assumptions accounted for the possibility of future change in rural areas. The optimistic scenario was developed on the assumption that the undertaken adaptive measures would focus on greening in agricultural holdings and afforestation according to the concept proposed by the Polish government. The pessimistic scenario was developed on the assumption that human activities would not be adapted to climate change, while space would change according to the scenarios described by the Norwegian Meteorological Institute and insurance companies. The results demonstrated that the vulnerability index will continue to increase, unless adaptive measures are undertaken. Therefore, adaptive measures have to be implemented to increase the resistance of entities to the losses caused by extreme weather phenomena.
\end{abstract}

Keywords: climate change, land use, rural area.

\section{Introduction}

Climate change has been researched extensively in recent years. Climate change is driven by two types of factors: external, such as insolation reaching the surface of the Earth, and internal, which are associated with human activities [1]. The direct consequences of climate change are experienced by the human population around the globe [2-3]. They include spells of very hot weather, forest fires, droughts, which are increasingly often experienced in Southern and Central Europe, and the Mediterranean Region, and higher risk of flooding in Northern Europe. European cities face new perils associated with hot weather, floods and rising sea levels. Research into preventive and adaptive measures for protecting various sectors of the economy against climate change aims to increase the resilience of communities, space, critical infrastructure and incomes to adverse weather phenomena [4-5]. Humans are responsible for changes in land use, therefore, they should also be able to influence the climate and, consequently, the severity of adverse weather events [6-7]. The intensity and frequency of adverse weather phenomena are driven by climate change and can be exacerbated by local conditions. According to Koźmiński [8], ground frost is determined mainly by the land form, land cover, soil type, the hydrographic network and the presence of forests and mountains. Plants are at greater risk of damage in regions characterized by significant temperature fluctuations and the disappearance and reappearance of snow and ice cover in early spring. Soils on south-facing slopes are heated at a faster rate and are more exposed to moisture loss and drought than north-facing slopes [9]. According to Żak [10], climatic conditions on the microscale and mesoscale are also significantly influenced by geological depressions, in particular basins, which are characterized by adverse temperature inversions, namely the flow of cold air masses to the basin floor and the lifting of warm air. These processes are responsible for the formation of cold air pools, which have highly detrimental effects for agriculture, in particular orchards and vegetable farms. The local climate is highly correlated with soil conditions and the hydrological regime of a habitat [11]. Areas situated close to bodies of flowing water are at higher risk of flooding, and the resulting increase in humidity can exacerbate frost-damage in plants [12]. According to Kostrakiewicz [13], large bodies of water can also increase the wind speed. Waterlogged areas stabilize and retain water resources, and they contribute to the preservation of biological diversity [14]. Small mid-field ponds accumulate water, increase water retention in soil and raise the water table in the surrounding areas [15]. According to Mioduszewski [16], catchments occupied by wetlands and water bodies in $40 \%$ retain more than $90 \%$ of pollutants from agricultural production. The abundance of surface water bodies, marshes and forests 
alleviates sudden temperature fluctuations and decreases the wind speed. Forests shape the microclimate, reduce local pollution and increase water retention [17]. They limit water evaporation from the surface of soil, minimize soil drying during spells of hot weather in summer and cold weather in winter, limit daily fluctuations in temperature, reduce the severity of ground frost in early spring, and act as natural barriers against the transport of harmful and toxic chemicals from mineral fertilizers and pesticides [18]. According to the Forests and Water Resolution signed by more than 40 European countries, sustainable management of forests enhances the protective functions of forests for water and soil and mitigates local water-related natural disasters. Afforestation and sustainable forest management are the most effective methods of compensating for the anthropogenic emissions of carbon dioxide, one of the main greenhouse gasses that contribute to climate change $[19 ; 20]$.

The aim of this study was to analyze the influence of land use on climate change. An indicator for determining the susceptibility of space to climate change was developed and used in the analyses. Calculations were performed based on simulations of changes in selected land-use attributes to determine the extent to which land use can drive climate change.

\section{Methods}

The index of vulnerability to climate change was based on an aggregate measure. Aggregate measures transform the numerous attributes of the analyzed object into a single aggregate variable. This approach is used to evaluate an object (municipality) with the use of a single variable and to rank the examined objects in view of the analyzed phenomena. According to Sokołowski [21], aggregate measures have several advantages:

- unitarization (the distance between a given value and the "worst" observed value is divided by the range) in the postulated form and averaging with the arithmetic mean are formally accepted methods;

- aggregate measures conform to the detailed requirements for synthetic measures;

- the measure is expressed on a scale of 0 to 100 points;

- the proposed unitarization and aggregation methods are universally applied in the process of calculating the Human Development Index;

- the proposed measure combines the attributes of anti-pattern and pattern detection methods.

Anti-pattern methods typically rely on averaged normalized values. However, in the adopted normalization and aggregation method, the distance from the anti-pattern is calculated based on the averaged value of a single attribute, which is typical of pattern methods. The $I P$ index was calculated with formula (1), and unitarization was carried out with the use of formulas (2) and (3):

$$
I P=\left(\frac{\sum_{n}^{i} w_{i u}}{n}\right) \cdot 100,
$$

where $w_{i u}-$ variable unitarized with formulas (2) and (3);

$n$ - number of attributes;

for stimulating variables

$$
x_{i j}=\frac{x_{i j}-\min \left\{x_{i j}\right\}}{\max \left\{x_{i j}\right\}-\min \left\{x_{i j}\right\}},
$$

for destimulating variables

$$
x_{i j}=\frac{\max \left\{x_{i j}\right\}-x_{i j}}{\max \left\{x_{i j}\right\}-\min \left\{x_{i j}\right\}},
$$

where $i$ - number of the object;

$j$ - number of the attribute.

The analyzed measure was determined with the attributes presented in Table 1. 
List of the analyzed attributes

Table 1

\begin{tabular}{|c|l|c|}
\hline No. & \multicolumn{1}{|c|}{ Attribute } & Measure \\
\hline 1 & Agricultural climate points \\
\hline 2 & Landform & points \\
\hline 3 & $\begin{array}{l}\text { Proportion of water bodies (standing water, flowing water, } \\
\text { seawater) in the area of a municipality }\end{array}$ & $\%$ \\
\hline 4 & $\begin{array}{l}\text { Value of losses caused by extreme weather events in the years } \\
\text { preceding the study }\end{array}$ & PLN \\
\hline 5 & $\begin{array}{l}\text { Number of extreme weather events in the analyzed period in } \\
\text { the examined municipality }\end{array}$ & number \\
\hline 6 & $\begin{array}{l}\text { Proportion of permanent grasslands (meadows and pastures) in } \\
\text { the area of a municipality }\end{array}$ & $\%$ \\
\hline 7 & Forest cover in a municipality & points \\
\hline 8 & Agricultural land classification & $\begin{array}{c}0 \text {-none } \\
\text { 1-present }\end{array}$ \\
\hline 9 & Presence of Less Favored Areas \\
\hline
\end{tabular}

Source: own elaboration

The studied objects were rural municipalities in north-eastern Poland.

\section{Results and Discussion}

The index of vulnerability to climate change was calculated with the use of formula (1), and every attribute was standardized according to formulas (2) and (3) by determining the direction of the attributes' influence (stimulating or destimulating). The value of the index ranged between 0 and 100 points. The maximum value points to high susceptibility to climate change, and the minimum value points to lower susceptibility to climate change. The calculated index values with the corresponding vulnerability groups are presented in Fig. 1. Municipalities that are most susceptible to climate change (index values higher than 50) are situated in the southern, central and eastern parts of the analyzed area. The least vulnerable municipalities are distributed in the form of isolated points.
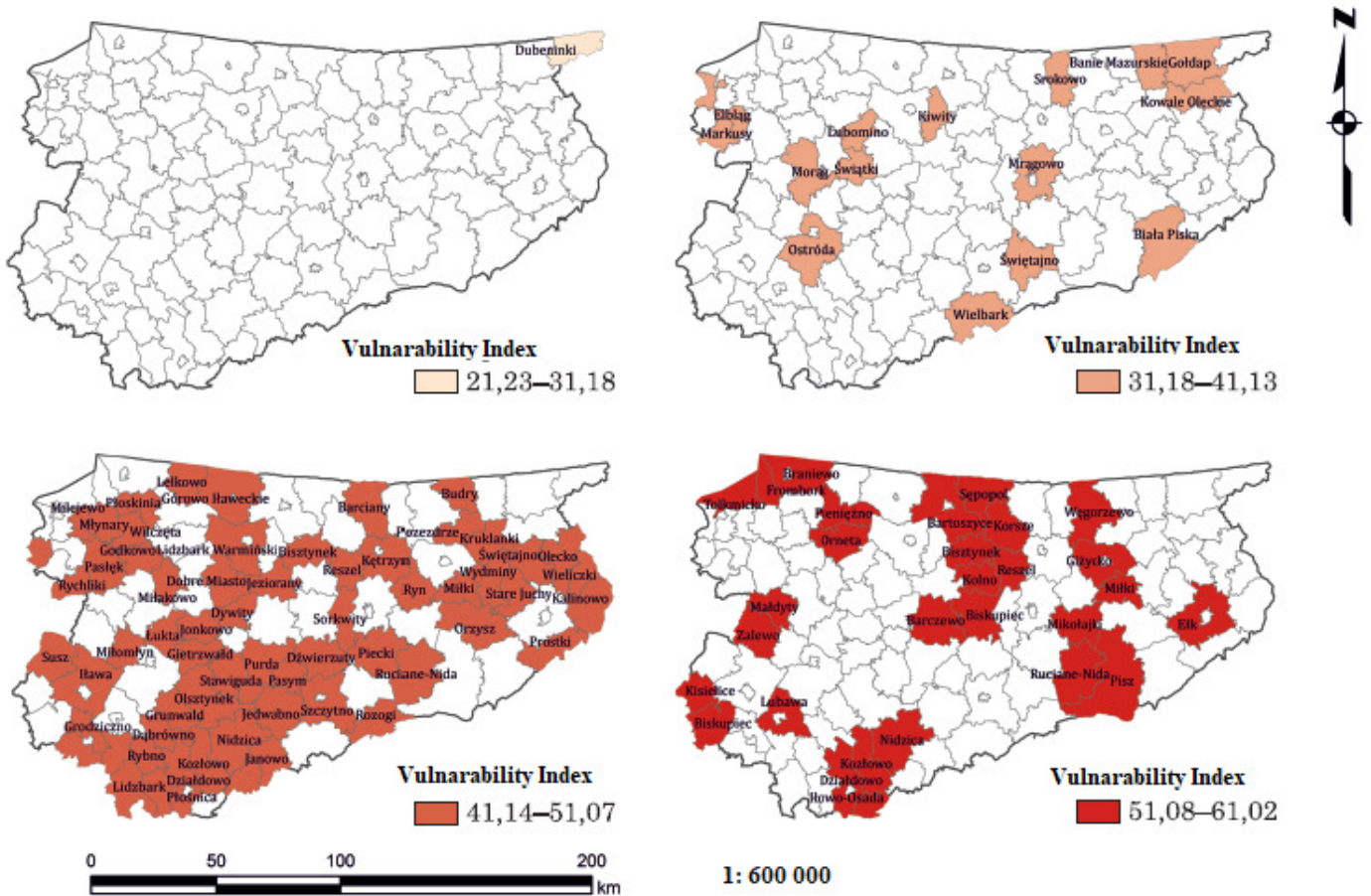

1: 600000

Fig. 1. Spatial distribution and range of values of calculated index of vulnerability to climate change, source: own elaboration 
In the second stage of the study, changes in land use were simulated over a 5-year horizon, and changes in the intensity of extreme weather events for Eastern Europe were predicted according to the data of the Norwegian Meteorological Institute [22]. Changes in land use result from Poland's afforestation policy and an increase in the proportion of permanent grasslands resulting from agricultural, environmental and climate projects under the Rural Development Program (PROW) 2014-2020 co-financed by the European Union. The changes in the value of the calculated index for the analyzed municipalities relative to changes in land use (afforestation, conversion of arable land to grassland) are presented in Fig. 2.

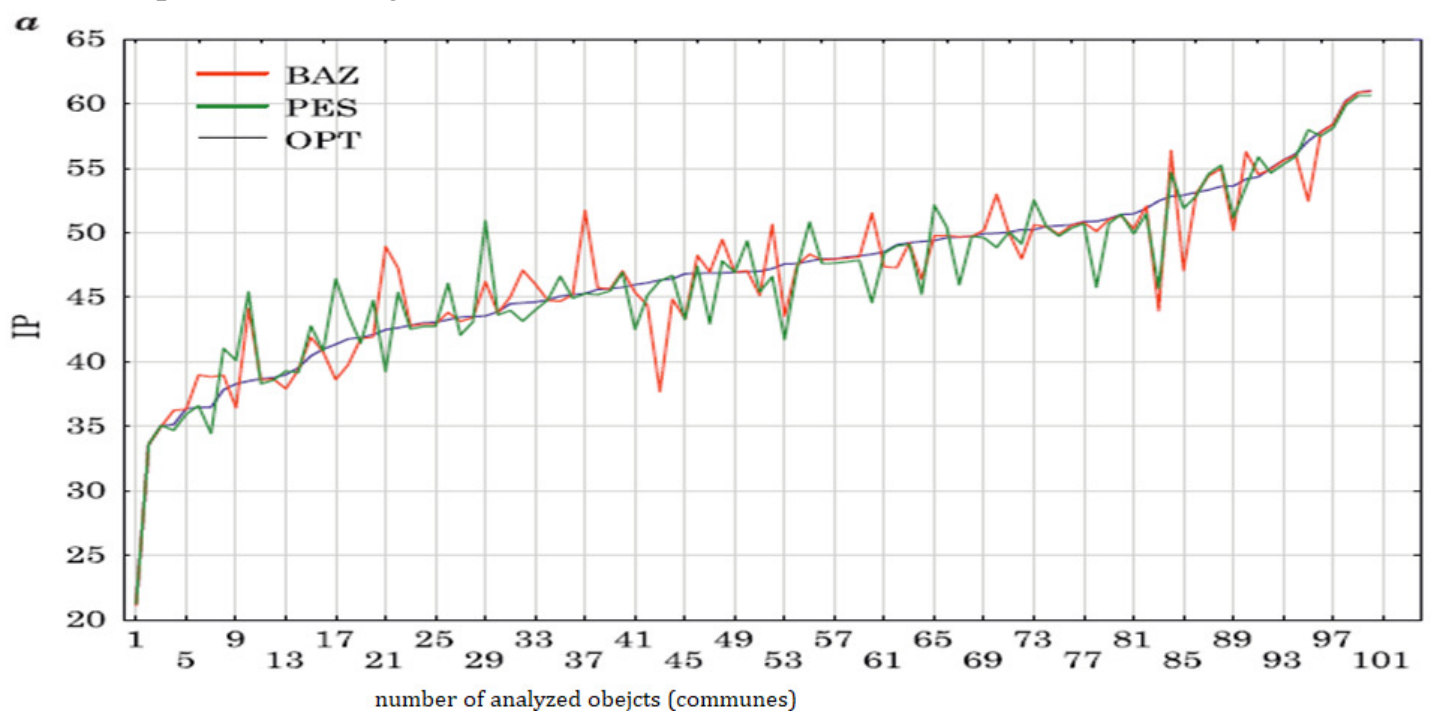

Fig. 2. Changes in value of index of vulnerability to climate change, source: own calculations in the Statistica 12 program

The changes in the values of the calculated index are presented in Fig. 2. The value of the index at the time of the study is marked in red (BAZ), the value of the index in the pessimistic scenario, where adaptive measures are not undertaken and the frequency of extreme weather events predicted by the Norwegian Meteorological Institute increases, is marked in green (PES), and the value of the index in the optimistic scenario, where adaptive measures are implemented (increase in afforestation to $35 \%$ and conversion of arable land to grasslands according to the provisions of PROW 2014-2020), are marked in blue (OPT).

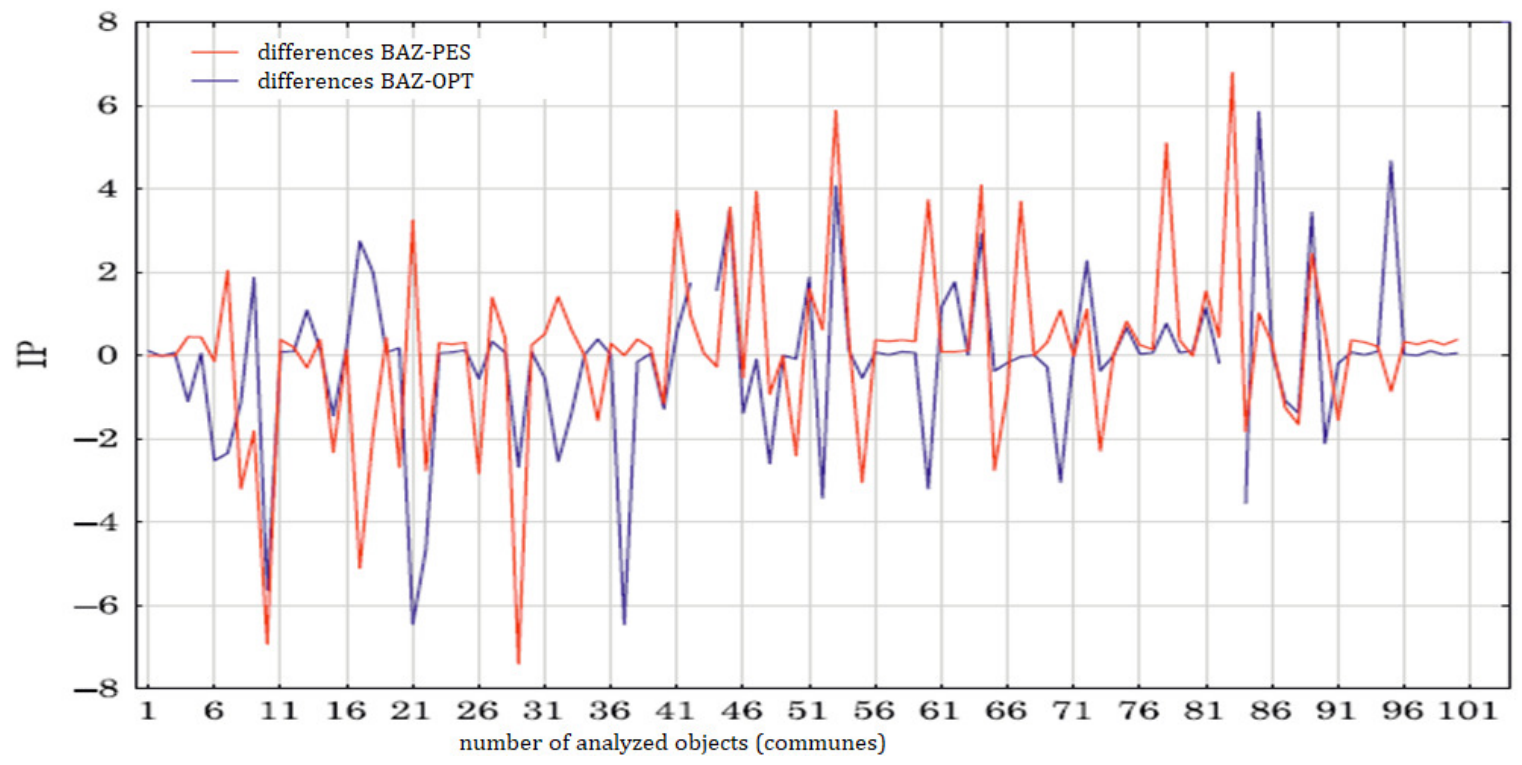

Fig. 3. Direct changes in value of vulnerability index in scenario where adaptive measures are implemented (blue) and are not implemented (red), source: own calculations in the Statistica 12 program 
In $90 \%$ of the analyzed municipalities, changes in land use decreased the value of the calculated index (Fig. 3). The value of the index increased in $10 \%$ of the examined municipalities, most of which are Less Favored Areas. The greatest variations in the index values were noted in the scenario, where adaptive measures were not implemented in rural areas. The introduction of adaptive measures decreased the fluctuations in the value of the analyzed index.

\section{Conclusions}

The results of this study support the formulation of the following conclusions:

1. Analyses investigating the influence of land use on climate change should be based on an index that accounts for local conditions.

2. The applied index should be an aggregate measure that accounts for various attributes of the evaluated object.

3. The proposed index is expressed on a scale of 0 to 100 points, and it is easy to interpret.

4. The evaluated municipalities were characterized by moderate and high vulnerability to climate change.

5. Changes in land use, including afforestation and the conversion of arable land to grasslands (meadows and pastures), decrease the value of the vulnerability index [23] and decrease a municipality's susceptibility to the adverse consequences of climate change under the adopted assumptions.

\section{Acknowledgements}

The research was financed by the Ministry of Science and Higher Education of the Republic of Poland [project No. 28.610.015-300].

\section{References}

[1] Kocur-Bera K. A safe space of rural areas in the context of the occurrence of extreme weather events - a case study covering a part of the Euroregion Baltic. Land Use Policy vol. 71, 2018, pp. 518-529; https://doi.org/10.1016/j.landusepol.2017.11.013.

[2] Kocur-Bera K. Intergenerational transmission of models of protection against the consequences of weather changes and the contemporary proposals for adaptation solutions in agricultural farms. Proceedings of the International Multidisciplinary Scientific Geoconference SGEM Vienna GREEN, Austria, November, vol. III, 2016, pp. 145-152.

[3] Kocur-Bera K. Sensitivity analysis of the index of a rural municipality's vulnerability to losses resulting from extreme weather events. Proceedings of 10th International Conference "Environmental Engineering" Vilnius Gediminas Technical University, Lithuania, 27-28 April, 2017, pp.1-7, DOI: https://doi.org/10.3846/enviro.2017.200.

[4] Cavallo E., Noy I. The economics of natural disasters. A survey. Inter-American Development Bank. IDB Warking Paper. Series No. IDB-WP-124, 2010. 50 p.

[5] Carrara A., Guzzetti F. (eds.). Geographical information systems in assessing natural hazards. Springer, New York, 1995. 345 p.

[6] Obrębska-Starklowa B. Wpływ zmian użytkowania ziemi w dolinie Raby na warunki termiczne zbiorowiska leśnego tllio-carpinetum (Influence of land use changes in the Raba valley on thermal conditions of Tilio-Carpinetum forest community). Monografia p.t. Współczesne badania topoklimatyczne pod redakcją Kuchcik M., Wyd. PAN Warszawa, 2001, pp. 59-73. (In Polish).

[7] Błażejczyk K.. Koncepcja przeglądowej mapy topoklimatycznej Polski (The concept of a topoclimatic overview map of Poland). Monografia p.t. Współczesne badania topoklimatyczne pod redakcją Kuchcik M., Wyd. PAN Warszawa, 2001, pp.131-141 (In Polish).

[8] Koźmiński C. Przygruntowe przymrozki w Polsce w latach 1963-1972 (Ground frost in Poland in 1963-1972). PWN, Poznań-Warszawa, vol. 40/3, 1974. 52 p. (In Polish).

[9] Witek T., Górski T., Kern H., Bartoszewski Z.,Biesiacki A., Budzyńska K., Demidowicz G., Deputat T., Flaczyk Z., Gałecki Z., Ganowicz M., Gondek W., Huczyński B., Ochalska L., Jarubas M., Jastrzebski M., Kuczaj W., Kwiecień L., Mrozowski J., Olejniczak E., Ostrowski K., Partyka A., Sotniczuk M., Zbysław B., Langhmer L. Waloryzacja Rolniczej Przestrzeni 
Produkcyjnej Polski Według Gmin (Valorisation of Agricultural Production Space of Poland According to Communes). IUNIG Puławy, 1981. 415 p. (In Polish).

[10]Żak M. Podstawy geodezyjnego urządzania gruntów rolnych (Basics of geodetic control of agricultural land). Wydawnictwo Akademii Rolniczej w Krakowie, 2006. 191 p. (In Polish).

[11] Konopko S. Różnice w klimacie lokalnym większych dolin rzecznych w Rejonie Bydgoszczy (Differences in the local climate of major river valleys in the Bydgoszcz area). Praca zbiorowa p.t. Metody opracowań topoklimatycznych. PAN, SGGW, Warszawa, 1980, pp. 95-105. (In Polish)

[12] Trought M.C.T., Howell, Cherry N. Practical Considerations for Reducing Frost Damage in Vineyards. Report to New Zealand Winegrowers, Lincoln University, 1999. 43 p.

[13] Kostrakiewicz L. Prognozy przemian klimatu w związku z budową zbiorników wodnych na Dunajcu koło Czorsztyna (Forecasts of climate change due to the construction of water reservoirs on the Dunajec near Czorsztyn). Studia Naturae, Ser. B, 30, 1982, pp. 508-513. (In Polish).

[14] Dobrowolski K.A., Lewnadowski K. (eds.). Ochrona środowisk wodnych błotnych w Polsce (Protection of mud water environments in Poland). Stan i perspektywy. Oficyna Wydawnicza Instytutu Ekologii PAN, Dziekanów Leśny, 1998. 183 p. (In Polish).

[15] Juszczak R., Kędziora A. Retencja małych zbiorników wodnych w zachodniej części zlewni Rowu Wyskoć (Retention of small water reservoirs in the western part of the Rawka Wyskoć catchment). Roczniki AR Poznań, vol. 25, 2004, pp.193-200. (In Polish)

[16] Mioduszewski W. Gospodarowanie zasobami wodnymi w aspekcie wielofunkcyjnego rozwoju obszarów wiejskich (Water resources management in view of multifunctional development of rural areas). Woda-Środowisko-Obszary Wiejskie vol. 4 z. 1(10), 2004, pp. 11-29. (In Polish)

[17] Smith W.H. Air Pollution and Forests: Interactions Between Air Contaminants and Forest. DOI: 10.1007/978-1-4684-0104-2.Springer-Verlag New York, 1989. 379 p.

[18] Symonides E. Znaczenie powiązań ekologicznych w krajobrazie rolniczym (The role of ecological interactions in the agricultural landscape). Woda- Środowisko-Obszary Wiejskie,vol. 10, issuel 4 (32), 2010, pp. 249-263. (In Polish).

[19] Van der Werf G.R., Morton D.C., DeFries R.S., Olivier J.G., Kasibhatla P.S., Jackson R.B., Collatz G. J., Randerson J. T. CO2 emissions from forest loss. Nature Geoscience 2, 2009,pp.737-738.

[20]FAO \& JRC, Global forest land-use change 1990-2005, by E.J. Lindquist, R. D’Annunzio, A. Gerrand, K. MacDicken, F. Achard, R. Beuchle, A. Brink, H.D. Eva, P. Mayaux, J. San-MiguelAyanz \& H-J. Stibig. FAO Forestry Paper No. 169. Rome, 2012. 40 p.

[21] Sokołowski A. Analizy wielowymiarowe (Multivariate analysis). Materiały szkoleniowe StatSoft Polska, 2014, pp.55. (In Polish)

[22] Hov Ø., Cubasch U, Fischer E., Höppe P., Iversen T., Kvamstø N.G., Kundzewicz Z.W., Rezacova D., Rios D., Santos F.D., Schädler B., Veisz O., Zerefos CH., Benestad R., Murlis J., Donat M., Leckebusch G.C., Ulbrich U. Extreme Weather Events 462 in Europe: preparing for climate change adaptation. ISBN (print) 978-82-7144-100-5, 2013, pp.1-7.

[23] Kocur-Bera K. The role of forests in mitigating the adverse consequences of extreme weather events. Proceedings of 17th International Multidisciplinary Scientific Geoconference SGEM Vienna Green, Austria, vol. 17, 2017, pp.657-664, DOI: 10.5593/sgem2017H/33/S14.082. 